Sustinere

Journal of Environment and Sustainability

Volume 1 Issue 2 (2017) 94-98

Print ISSN: 2549-1245 Online ISSN: 2549-1253

Website: https://sustinerejes.com E-mail: sustinere.jes@iain-surakarta.ac.id

\title{
RESEARCH PAPER \\ Study of turbidity treatment in Karangpilang II Water Treatment Plant
}

\author{
Arief Rahman*, Ali Masduqi \\ Department of Environmental Engineering, Sepuluh Nopember Institute of Technology (ITS) \\ Surabaya, Indonesia \\ Article history: \\ Received 2 August 2017 | Accepted 2 Oct 2017 | Available online 29 December 2017
}

\begin{abstract}
Karangpilang II Water Treatment Plant (WTP) is a part of Karangpilang WTP of Surabaya Water Utilities that serves the water supply for Surabaya City. Karangpilang II WTP has the biggest clean water production capacity in Karangpilang WTP, which is $2500 \mathrm{~L} / \mathrm{s}$. Using conventional treatment to remove turbidity, the treatment plant in Karangpilang II WTP consists of pre-sedimentation, clearator and filter units. In this study, evaluation of turbidity quality in production water and turbidity removal efficiency were conducted to analyze the Karangpilang II WTP performance in turbidity treatment. The evaluation was conducted using the 2016 data, by comparing the turbidity of production water with the Water Quality Standard of the Water Utilities, and by comparing the turbidity of raw water, effluents of each treatment unit and production water. The evaluation result showed that in the case of Karangpilang II WTP turbidity removal performance, there were some occurrences that the turbidity in production water has not met the standard quality. The results also showed that there was a unit in the Karang Pilang II WTP with inadequate performance in turbidity removal, namely pre-sedimentation unit. There are some solutions for the problem of turbidity removal in Karangpilang II WTP: increasing the maintenance schedule for presedimentation unit; determining the proper turbidity reference in determination of coagulant dose; optimizing the coagulant dose; using produced sludge from water treatment as coagulant aid along with $\mathrm{Al}_{2} \mathrm{SO}_{4}$; and using capping material in filter unit.
\end{abstract}

Keywords: raw water quality; production water quality; Karangpilang II Water Treatment Plant; performance; treatment unit

\section{Introduction}

Surabaya is one of the metropolitan cities in Indonesia that has a population growth up to $0.63 \%$ (Badan Pusat Statistik Kota Surabaya, 2016). Population growth in Surabaya City triggers the increase of water demand. This leads the Goverment of Surabaya City needs to maintain the adequacy of water supply in Surabaya City. 
PDAM Surya Sembada is a company owned by regional government that serve the water supply in Surabaya City, which consists of Ngagel and Karangpilang Water Treatment Plants (WTP). As the biggest provider of clean water in Karangpilang, Karangpilang II WTP has a clean water production capacity of $2500 \mathrm{~L} / \mathrm{sec}$ needs to be evaluated. So it's performance to meet the quality requirement in turbidity treatment may be maintained. Thus, it's not only going to meet the quantity requirement, but also the quality requirement.

Karangpilang II WTP uses conventional treatment to treats raw water taken from Surabaya River, and it is being focused to treat turbidity. The treatment unit consists of pre-sedimentation, clearator and filter units. The evaluation of Karangpilang II WTP was being conducted by comparing the quality of turbidity between production water and the Water Quality Standard of PDAM, and comparing the quality between turbidity in raw water, in each treatment units and in production water. The evaluation results were used for finding the problems in turbidity treatment in Karangpilang II WTP, and determining the solution to solve the problems.

The results showed that in turbidity treatment of Karangpilang II WTP, there were some occurrences in which the quality of turbidity in production water is still unable to meet the quality standard, and the pre-sedimentation unit is still unable to reach it's optimum efficiency due to some conditions.

\section{Methodology Statistical analysis}

The treated turbidity in Karangpilang WTP was being analyzed by conducting a stastistical analysis using Paired t-test. The results showed that there is a difference between the mean of the daily turbidity data of raw water from 2016 and of the daily turbidity data of production water from 2016 of Karangpilang II WTP.

\section{Analysis of quality}

Analysis of quality was conducted to evaluate if the quality of turbidity in production water met the quality standard. The analysis was conducted by comparing the quality data of turbidity in production water from 2016 and the Water Quality Standard of PDAM.

\section{Analysis of efficiency}

Analysis of efficiency is being conducted to check the efficiency of Karangpilang II WTP and the efficiency of each unit in Karangpilang II WTP using the data of turbidity quality from 2016. The analysis was conducted as follows; first, by comparing quality of turbidity between raw water and the outlet of pre-sedimentation unit. This was conducted to find the efficiency of pre-sediemtation unit. Second, by comparing the data of turbidity quality between the outlet of pre-sedimentation unit and of clearator unit. Itp was carried out to find the efficiency of clearator unit. Third, quality data of turbidity between the oultet of clearator unit and the outlet of filter unit is compared to find the efficiency of filter unit. Fourth, quality data of turbidity between raw water and production water is compared to find the efficiency of Karangpilang II WTP. 


\section{Result}

\section{Statistical Analysis}

Statistical analysis was conducted using paired $t$-test and showed that there is a significant difference between the mean of the daily turbidity data of raw water from 2016 and the mean of the daily turbidity data of production water from 2016 of Karangpilang II WTP. It proves that there is a reduction of turbidity in turbidity treatment in Karangpilang II WTP, so it also proves that Karangpilang WTP is able to treat turbidity in raw water.

\section{Analysis of quality}

The result of quality analysis showed that there are some occurrences from quality of turbidity in production water which has still not met the quality standard of 1 NTU, 28 times in 2016. The quality data of turbidity in production water from 2016 in Karangpilang WTP is shown in Figure 1.

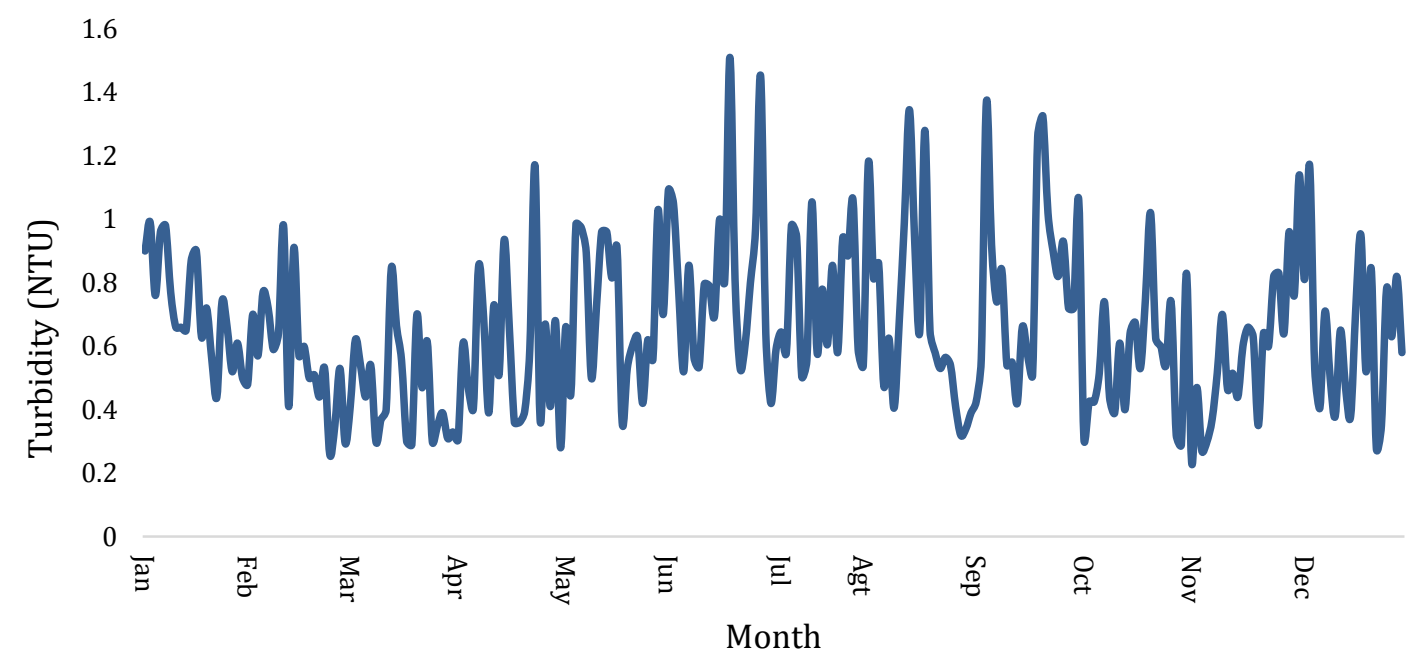

Figure 1. Graphic of quality of turbidity in production water from 2016 of Karangpilang II WTP (PDAM Surya Sembada, 2016)

\section{Analysis of efficiency}

The results of analysis of efficiency showed that throughout 2016, all of efficiency of Karangpilang II WTP in turbidity treatment are above 90\%. It indicates that, overall, the performance of Karangpilang II WTP in turbidity treatment is in a good condition. Nonetheless, there are some occurrences of turbidity quality that has still not met the quality standard, hence, the Karangpilang WTP needs to make some improvement in order to fix the problem.

The analysis of efficiency for each unit in Karangpilang II WTP showed that the efficiency of pre-sedimentation unit is in the range of 5.9-34.7\%. It indicates that presedimentation unit in Karangpilang II WTP is not in a proper condition, because based on the theory, pre-sedimentation unit may reduce turbidity up to 40-60\% (Joko, 2010). Therefore, pre-sedimentation unit in Karangpilang WTP needs to be improved, so it can reach the proper efficiency according to the theory. The alternative solution that may be 
conducted as improvement effort are increasing the maintenance schedule that has been only conducted once per month and increasing the detention time in pre-sedimenation unit.

According to the effciency analysis, the efficiency of clearator unit in WTP Karangpilang is in the range of 70.1-94.8\%. It shows that clearator unit in Karangpilang II WTP is in a good condition. However, the improvement efforts still need to be conducted, so that clearator unit in Karangpilang WTP can reach it's highest capability in turbidity treatment. The alternative solutions that may be conducted to improve the performance of clearator unit in Karangpilang WTP are:

- Using the turbidity quality of pre-sediment outlet as the reference in determination of coagulant dose (Karangpilang WTP has been using the turbididy quality in raw water as reference in determination of coagulant dose, assuming that the turbidity quality in the outlet of pre-sedimentation is similar with the turbidity quality in raw water).

- Optimizing the coagulant dose, refers to the turbidity, $\mathrm{pH}$, temperature and stirring intensity (Hadi, 2012).

The result of efficiency analysis showed that the efficiency of filter unit in Karangpilang II WTP is in the range of $80.4-89 \%$. According to the theory, filter unit may remove the turbidity up to $50-95 \%$ (Degrémont, 1991) or $90-98 \%$ if the water turbidity is in the range of 5-10 NTU (Masduqi \& Assomadi, 2012). It indicates that performance of filter unit of Karangpilang WTP in turbidity treatment is in a good condition. However, the improvement efforts still need to be conducted, so that filter unit in Karangpilang II WTP can reach it's highest capability in turbidity treatment. Optimizing the detention time in filter unit may be conducted as an alternative solution to improve filter unit performance.

\section{Conclusions}

After analyzing the data, the researcher concluded that Karangpilang II WTP needs to improve it's performance in turbidity treatment, so that the occurences of turbidity quality which has not met the Water Quality Standard of PDAM could be fixed and will not occur in the future. The performance of pre-sedimentation of Karangpilang II WTP needs to be improved because the efficiency of the unit is still unable to reach the efficiency as mentioned in the theory.

\section{Acknowledgement}

We would like to thank PDAM Surya Sembada for the data provided for this study.

\section{References}

Badan Pusat Statistik Kota Surabaya (2016), Kota Surabaya Dalam Angka Tahun 2016, Surabaya.

Degrémont (1991). Water Treatment Handbook, 6th edition, Vol. 2, Lavoisier, Paris.

Hadi, W. (2012). Perencanaan Bangunan Pengolahan. ITS Press, Surabaya.

Joko, T. (2010). Unit Produksi Dalam Sistem Penyediaan Air Minum. Graha Ilmu, Yogyakarta. 
Masduqi, A. and Assomadi, A.F. (2012). Operasi dan Proses Pengolahan Air. ITS Press, Surabaya.

PDAM Surya Sembada (2016). Evaluasi Kehandalan Supply Air Minum Dari IPAM ke Pelanggan, Laporan Akhir, Surabaya. 